Available online at: https://tsdr.psdku.unpad.ac.id/index.php/journal/index

Tourism and Sustainable Development Review Journal (TSDR)

ISSN 2722-2152 (online)

Volume 2 Number 2 (2021): 30-39

\title{
Sustainable Tourism in Northern Iloilo: Perceived Impact and Prospects for Development
}

\author{
Cherryl C. Sainz 1, Maria Corazon M. Samorin' \\ ${ }^{1}$ College of Hospitality Management, Northern Iloilo Polytechnic State Collage -Barotac Viejo Campus, \\ Philippines \\ ${ }^{2}$ College of Business and Management, West Visayas State University, Philippines
}

\begin{abstract}
This survey-correlational study, conducted in January 2016, aimed at ascertaining the impact and prospects for the development of sustainable tourism in Northern Iloilo. Two hundred (200) randomly selected residents of selected municipalities from Northern Iloilo were utilized as participants. The cluster sampling method was used in the selection of participants. The Tourism Impact Questionnaire was utilized to measure the impact of sustainable tourism, while the Prospects for Sustainable Tourism was adapted to measure the level of viability of the prospects of sustainable tourism in Northern Iloilo. Data, frequency, percentage, mean, and standard deviation were employed as descriptive statistics, while the t-test, one-way ANOVA and Pearsons $r$ were used as inferential statistics. Study results revealed the high impact of Northern Iloilo on the sustainability of tourism as perceived by the residents. Sustainable tourism in Northern Iloilo was found to have very high prospects for development. A positive and significant relationship existed between the assessed impact and viability of the prospects for development of the sustainable tourism in Northern Iloilo.
\end{abstract}

Keywords: Impact; prospects for development; Northern Iloilo; sustainable tourism

This is an open access article under the CC-BY-NC license.

\section{INTRODUCTION}

Tourism is a major global industry (Libosada \& Bosargit, 2007). Its contribution to economic development has encouraged countries to pursue this dynamic sector. It's no wonder, then, that tourism has been called "one of the century's most extraordinary economic and social phenomena."

For a long time, tourism was seen as a "warm" operation, essentially conservatory, distinct from other types of production because its survival depended on the protection of the natural resource base and local cultures. It is now understood, however, that tourism is an industry like any other, an industry that has been marked by fast, short-term projects that have also destroyed the very assets they rely on.

"Tourism kills tourism" is accepted as a generalized phenomenon. Tourism is fundamentally an exploitative enterprise, and as such, as in all other polluting industries, it is justified to control tourism. The need for the tourism sector to become competitive is clear.

Corresponding author

Cherryl C. Sainz, chekai_022511@yahoo.com

DOI: https://doi.org/10.31098/tsdr.v2i2.51

Research Synergy Foundation 
Sustainable tourism is described by the World Tourism Organization (Cernat \& Gourdon, 2012) as a creation that meets the needs of current visitors and host regions while also preserving and improving prospects for the future. It is hoped that it will contribute to resource management that meets economic, social, and creative needs while also safeguarding cultural identity, vital ecological cycles, biodiversity, and life support systems.

Tourism is inherently an abusive enterprise, and as such, like any other polluting industry, it is essential to regulate tourism. The need for the tourist industry to become prosperous is clear. Sustainable tourism is becoming so common that some predict that in ten years, what is now considered an alternative will be mainstream. Various types of complementary or sustainable tourism, such as "nature-based tourism," "ecotourism," and "cultural tourism," are among them (UNESCO, 2014).

A movement to encourage sustainable tourism activities concerning the management of tourist destinations by locals or the city has been launched. This is focused on the idea that the people who live around a resource are the right people to protect it. This ensures that local community members establish and run tourism programs and enterprises, and they do so with their approval and assistance. Sustainable tourism usually entails the preservation of tourismrelated infrastructure.

This study is anchored on the sustainable development theory of Vito Di Bari, which states that sustainable development is about the development of a region, a country or a community that meets the needs of the present without compromising the ability of future generations to meet their own needs. It is composed of its four pillars, namely, ecology, economics, politics and culture (UNESCO, 2014).

Henceforth, these developments brought by tourism to Northern Iloilo is a big milestone to the posterity of the city, but these remains indefinite as to whether the impacts and the sustainable development brought along can either make or break the natural beauty of the area. As tourism frontline, the perceived impacts and the prospects for development in Iloilo City as assessed by the tourists are as well uncertain.

\section{LITERATURE REVIEW}

Protecting the environment has become a major issue in recent years. Nowadays, most people are aware of the fact that our planet has quite limited natural resources. According to Buhalis and Fletcher (1995 as cited in Stoyanov, 2012), people are starting to realize the impact that environmental destruction could have and the idea that each generation has the same right to live in an unpolluted and safe environment constantly gains popularity. The view that the planet we live in, often referred to as "our" planet, is not our property but borrowed and should be returned in analogous if not better condition to the next generations is spreading rapidly in the modern world. However, often, environmental concern is in conflict with the short-term economic benefits of numerous companies, which increase their short-term profits with little concern for the environment.

Over the last two decades, the concept of sustainable tourism development has become almost universally accepted as a desirable and politically appropriate approach to tourism development (Sharpley, 2003). The tourism industry should be encouraged to embrace clean green tourism, which means that firms should do their best to decrease the environmental impacts of 
their operations. If a destination is to achieve sustainable tourism development, then the actions of its constituent firms must be consistent with and support this objective. Dwyer and colleagues, in a study, stated that tourism firms should adopt a Triple Bottom Line (TBL) approach to sustainable development to ensure that firms integrate social, environmental and economic information into managerial decision-making. Firms must aim to achieve sustainability in their operations if the destination as a whole is to conform to sustainability principles (Dwyer, Edwards, Mistilis, Roman, \& Scott, 2009)

According to Weaver (1998 as cited in Bac, 2012), the new form of practicing tourism involved small companies or entrepreneurs, which aimed to support the community, preserving the environment and protecting local culture. One of the most prominent spokesmen of sustainable tourism, David Weaver, considers that "the main difference between the old and the new form of tourism is moving the focus from the wellbeing of the tourist to the wellbeing of the host community."

For Liu (2003), sustainable tourism is "all forms of tourism (conventional or alternative) that are compatible with and contribute to sustainable development." In the context of this definition, development does not necessarily imply growth, being essentially a process by which specific social and economic objectives are achieved. Achieving these goals may involve stabilization, growth, reduction, or even disappearance of existing products, companies or even industries.

Likewise, sustainable tourism development has been defined as "tourism in development that leads to management of all resources in such a way that economic, social and aesthetic needs can be fulfilled while maintaining cultural integrity, essential ecological processes, and biological diversity and life support systems (Tourism Canada, 1990; World Tourism Organization, 1996).

Furthermore, WCED (1987 in Huang, 2012) defined sustainable tourism as a process to meet the needs of the present without compromising the ability of future generations to meet their own needs. According to this definition, sustainable development essentially contains two key concepts: one is the needs of people, especially the poor's needs in the world, which is prioritized by exceeding everything's status; the second is the limitation of natural resources or environment, if the limitation is breakthrough, it will for certain to affect the living ability of people at present and in the future, and lead to various possible social problems. Under this context, it implicates that there are three important indicators for weighting sustainable development are: economic indicator, environmental indicator and social indicator, which all work together for sustainability and cannot be separated. In other words, sustainable development is to build a better life for all people in the world, regardless of different ages, races or gender, the world's resources and benefits should be distributed equally on the basis of sound exploitation and utilization, and could be further recycled or reused or regenerated by future generation.

Liu et al. (2013) highlight the precise definition of sustainability, which implies the significant role of states in preparing steady progress in living conditions for generations to come; sustainable development is more process-oriented and associated with managed changes that cause improvement in conditions for those involved in such development, and sustainable tourism is defined as all types of tourism that are compatible with or contribute to sustainable development. Sustainable tourism requires both the sustainable growth of tourism's contribution to the economy and society and the sustainable use of resources and the environment, which will be gained by a deep understanding and proper management of tourism demand. 
Cruz (2009) considered tourism to be sustainable when: it is economically profitable; it diversifies the economy but does not cause disruptions of critical industries; it provides livelihood and income opportunities for local people; it uses local labor and materials as much as possible; it preserves and even enhances the natural resources base; it does not disrupt ecosystems to a point as to endanger the survival species; it promotes prudent use of non-renewable resources; it promotes the use of clean energy; it revives, preserves local traditions and crafts and generates creativity in the arts; it promotes gender equality, opportunities for the youth and respects for the rights of indigenous peoples, it takes a long term perspective; it considers welfare of the future generation; it promotes equitable distribution of benefits; it promotes cooperation and partnerships; it promotes responsibility and accountability in behavior among tourist, the industry and local people, it does not violate morals and sensibilities of both resident and tourists; it integrates environmental and cultural considerations into tourism planning; and it emphasizes capacity building (training, education, research, and technical assistance).

Liu et al. (2013) concluded that the purpose of sustainable tourism is to make a balance between protecting the environment, maintaining cultural integrity, establishing social justice and promoting economic benefits, meeting the needs of the host population in terms of improved living standards both in the short and long term in both developed and emerging nations.

According to Ahn et al. (2002 as cited in Mbaiwa \& Stronza 2009), sustainable tourism seeks to meet three overarching goals: to improve the quality of life for host communities, to achieve visitor satisfaction, and to protect natural resources in destinations countries.

In summary, UNWTO (2010) stresses that sustainable tourism is maintaining a high level of tourist satisfaction, ensuring meaningful experience while raising their awareness about sustainability issues and promoting sustainable practices. It is a continuous process requiring constant monitoring of impacts, introducing necessary preventive and corrective measures.

\section{RESEARCH METHOD}

The survey correlational research design was utilized in this study. According to Creswell (2014), survey design examines a sample of a population to offer a quantitative or numeric overview of patterns, behaviors, or opinions. Survey because it is an efficient method for systematically collecting data from a broad spectrum of individuals and educational settings. On the other hand, correlational design describes and measures and the degree of association (relationship) between two more variables or sets of scores.

\section{Participants}

The participants of the study were the 200 randomly selected residents of Carles, Estancia, Barotac Viejo, and Concepcion, Iloilo, who were able to reach high school education. They were selected through cluster sampling. A sampling technique used where "natural" yet relatively heterogeneous groupings are apparent in a statistical community is cluster sampling. In consumer analysis, it is also used. The entire population is separated into these groups (or clusters) using this strategy, and a simple random sampling of the groups is chosen.

\section{Data-gathering instruments.}


To gather the data needed in this study, the Mohammadi, Khalifa, and Hosseini Tourism Impact Questionnaire (2010) was utilized to measure the impact of sustainable tourism, while the Mbaiwa \& Stronza (2010) Prospects for Sustainable Tourism was adapted to measure the level of viability of the prospects of sustainable tourism in Northern Iloilo.

The two adapted instruments were pilot tested to ascertain the validity and reliability in the local setting. Thirty (30) local residents were selected as respondents, and they were no longer included as final respondents of the study. The alpha coefficient for the items in the tourism impact questionnaire is .853, suggesting that the items have relatively high internal consistency. It is also true for the prospects for sustainable tourism questionnaire as it has an alpha coefficient of .874 . Indicating that the items have high internal consistency.

\section{FINDINGS AND DISCUSSION}

Data in Table 1 revealed a high impact of sustainable tourism in Northern Iloilo as perceived by residents when taken as an entire group or classified according to certain identified categories. This was revealed by the obtained mean scores, which fell within the $3.41-4.20$ scale.

Table 1. Level of Impact of Sustainable Tourism in Northern Iloilo

\begin{tabular}{|c|c|c|c|}
\hline Category & $\mathrm{M}$ & Description & SD \\
\hline A. Entire Group & 3.52 & High Impact & 0.21 \\
\hline \multicolumn{4}{|l|}{ B. Sex } \\
\hline Male & 3.50 & High Impact & 0.25 \\
\hline Female & 3.52 & High Impact & 0.19 \\
\hline \multicolumn{4}{|l|}{ C. Civil Status } \\
\hline Single & 3.51 & High Impact & 0.19 \\
\hline Married & 3.53 & High Impact & 0.24 \\
\hline \multicolumn{4}{|l|}{$\begin{array}{l}\text { D. Educational } \\
\text { attainment }\end{array}$} \\
\hline High school level & 3.48 & High Impact & 0.23 \\
\hline $\begin{array}{l}\text { High } \\
\text { graduate }\end{array}$ & 3.53 & High Impact & 0.21 \\
\hline College level & 3.50 & High Impact & 0.24 \\
\hline College graduate & 3.53 & High Impact & 0.21 \\
\hline \multicolumn{4}{|l|}{ E. Years as residence } \\
\hline Below 2 years & 3.42 & High Impact & 0.30 \\
\hline 2 to 5 years & 3.56 & High Impact & 0.21 \\
\hline 6 to 10 years & 3.53 & High Impact & 0.22 \\
\hline More than 10 years & 3.50 & High Impact & 0.20 \\
\hline
\end{tabular}


Tourism and Sustainable Development Review Journal (TSDR), Vol. 2 (2), 30-39

Sustainable Tourism in Northern Iloilo: Perceived Impact and Prospects for Development

Cherryl C. Sainz, Maria Corazon M. Samorin

\begin{tabular}{lrcr}
\hline $\begin{array}{l}\text { F. Family income } \\
\text { High } \\
\text { Average }\end{array}$ & 3.53 & High Impact & 0.20 \\
Low & 3.55 & High Impact & 0.21 \\
& 3.48 & $\begin{array}{c}\text { High } \\
\text { Impact }\end{array}$ & 0.23 \\
\hline
\end{tabular}

This result agrees with what Pearce (1994) has pointed out that perceived impacts are important from the point of view of assessing the community feeling.

There are many benefits and notably positive economic results for the tourism industry that sustainable tourism will bring to developing countries, which is seen as a way of reducing poverty. Tourism will generate options for the disadvantaged, and it helps them. Sustainable tourism is not able to automatically reduce suffering on its own. Tourism policies, as well as growth plans, should be in place, with the primary goal of reducing poverty.

Brida, Osti, and Disegna (2011) endorse this theory, stating that people who see tourism as a means of increased spending and improved public facilities will support policies aimed at the protection of natural and cultural capital.

Many researchers have found that residents' perceived impacts are strongly related to support for tourism. According to Gursoy et al. (2002), residents must help tourism growth in order for it to produce economic benefits. Tourism will produce employment, wages, tax revenue, solid infrastructure, and increased quality of life, investment prospects, and hard currency, according to impact reports (Hsu, 2000). In a nutshell, various studies have found that people who benefit the most from economic and socio-cultural changes are more likely to embrace tourism.

In general, as Chili (2015) points out, inhabitants of host communities have differing perspectives on the impacts of tourism. Residents who view tourism as having a positive effect are more likely to embrace conventional tourism growth and are more able to engage in a tourist exchange. Residents, on the other hand, are more likely to reject and oppose tourism growth and development if they believe it would result in more costs than benefits (Chen \& Chen, 2010; Jackson, 2008). According to Kuvan and Akan (2005), the trade-off between benefits and costs is often clarified by social exchange theory, which states that people would participate in and promote programs if the perceived benefits outweigh the perceived costs.

Data in Table 2 showed that sustainable tourism in Northern Iloilo has very high prospects for development as perceived by residents taken as an entire group or classified according to certain categories. This was revealed by the obtained mean scores that fell within the 4.21-5.0 range.

Table 2. Level of Viability of the Prospects for Development of Sustainable Tourism in Northern Iloilo

\begin{tabular}{lclc}
\hline Category & $\mathrm{M}$ & Description & SD \\
\hline $\begin{array}{l}\text { A. Entire Group } \\
\text { B. Sex }\end{array}$ & 4.38 & High Impact & 0.37 \\
\hline
\end{tabular}


Tourism and Sustainable Development Review Journal (TSDR), Vol. 2 (2), 30-39

Sustainable Tourism in Northern Iloilo: Perceived Impact and Prospects for Development Cherryl C. Sainz, Maria Corazon M. Samorin

\begin{tabular}{|c|c|c|c|}
\hline Male & 4.33 & High Impact & 0.39 \\
\hline Female & 4.41 & High Impact & 0.35 \\
\hline \multicolumn{4}{|l|}{ C. Civil Status } \\
\hline Single & 4.42 & High Impact & 0.35 \\
\hline Married & 4.34 & High Impact & 0.39 \\
\hline \multicolumn{4}{|l|}{$\begin{array}{l}\text { D. Educational } \\
\text { attainment }\end{array}$} \\
\hline High school level & 4.40 & High Impact & 0.36 \\
\hline $\begin{array}{l}\text { High } \\
\text { graduate }\end{array}$ & 4.40 & High Impact & 0.34 \\
\hline College level & 4.36 & High Impact & 0.41 \\
\hline College graduate & 4.35 & High Impact & 0.38 \\
\hline \multicolumn{4}{|l|}{ E. Years as residence } \\
\hline Below 2 years & 4.12 & High Impact & 0.25 \\
\hline 2 to 5 years & 4.35 & High Impact & 0.38 \\
\hline 6 to 10 years & 4.43 & High Impact & 0.36 \\
\hline More than 10 years & 4.38 & High Impact & 0.36 \\
\hline \multicolumn{4}{|l|}{ F. Family income } \\
\hline High & 4.39 & High Impact & 0.38 \\
\hline Average & 4.41 & High Impact & 0.34 \\
\hline Low & 4.35 & High Impact & 0.38 \\
\hline
\end{tabular}

The residents of Northern Iloilo believes that tourism activity occupies an important position in their economic, social, and cultural development. As such, they believed that there is something more to do in promoting their area as a sustainable tourism site.

Murthy (2008) supports this theory, stating that tourism is seen as the best possible and alternative method for improving multiple local communities. It is expected that tourism will lead to possible environmental protection, increased employment opportunities, increased public and private spending, the provision of infrastructure, and economic growth. The progress of tourism in rural communities has been a huge success factor for the local people in terms of creating jobs and providing an additional source of income.

In terms of contributing to long-term growth, tourism plays a significant role. Sustainable development is a significant philosophical paradigm for community and social development that also requires a long-term view of resource exploitation. Data in Table 3 showed that a positive and 
significant relationship existed between the level of impact of sustainable tourism and the level of viability of the prospects for development $(r=-.29, p=0.000), p<.05$.

There is a trend for rapid growth in today's global economy, an improvement in the amount of trade in the foreign market, a transformation of the transport industry, a rise in the internalization and convergence of the world's economic realms, an increase in the number of contractual partnerships, population visits related to economic activity. All of these are prospects that contribute to the development of tourism in a certain destination.

Residents who see tourism as a productive thing are more likely to promote sustainable growth, according to Chile (2015). According to Mi (2014), growth is at the heart of sustainable development, but it also necessitates stringent population management in order to increase quality, protect the environment, and foster economic and social development while adhering to the premise of resource sustainability. Citizens are the core body of sustainable growth, as comrade Jiang Zemin points out: "We can never fulfill our needs by undermining the future of the next generation" (Mi, 2014). Strong tourism effects and exciting growth opportunities go hand in hand. The lack of one has a negative impact on the other.

Table 3. Pearsons' $r$ Results for the Relationship Between Impact and Viability of the Prospects for Development of Sustainable Tourism in Northern Iloilo

\begin{tabular}{llc}
\hline & \multicolumn{2}{c}{ Viability of the prospects } \\
& \multicolumn{2}{c}{ for development } \\
& $r$ & $r$-prob \\
\hline Impact of sustainable tourism & $.291^{* *}$ & .000 \\
\hline$* * \mathrm{p}<.05$ & & \\
\hline
\end{tabular}

In terms of contributing to sustainable growth, tourism plays a significant role. To begin with, based on UNEP (2005) report, it is such a competitive sector that expands at a relatively fast rate and contributes a large amount of revenue year after year. Second, it is a connective tissue that bonds consumers, visitors, industry, the environment, and local communities.

Governments in developed countries encourage and facilitate tourism because of its strong multiplier effects in terms of creating jobs, growing foreign exchange earnings, improving the balance of payments, and boosting tourism supply sectors; additionally, both of these practices contribute to poverty alleviation (Croes \& Vanegas, 2008).

"Tourism is a commercial phenomenon of enormous global significance," according to Pender and Sharpley (2005). The enormous improvement in tourism's global contribution to the world economy cannot be overlooked; tourism is often referred to as the world's largest sector. However, it is expected that the enormous increase in tourism will continue in the future.

\section{CONCLUSION}

The residents appear to observe the improvement of the quality of life of people in Northern Iloilo brought about by sustainable tourism. This observation is in order due to optimized local economic benefits, protection of the environment, and provision of worthwhile experience to tourists and other types of visitors. 
Sustainable tourism appears to be a promising venture among residents of Northern Iloilo. Perhaps, the provision of livelihood and income opportunities, the enhancement of the natural resources, protection of the environment and the preservation of local traditions and crafts benefited the residents of Northern Iloilo.

Sex, civil status, educational attainment, years of residence in the area, and family income were factors found not to significantly influence one's perception of the impact of and prospects for the development of sustainable tourism. Regardless of whether one is a male or a female; single or married; at least attained high school education, high school graduate, at least college education or college graduate; had 2 years and below, 2 to 5 years, 6 to 10 years, or more than 10 years of residence in the area; has high, average, or low income, his/her assessment of the impact and prospects for development of sustainable tourism in Northern Iloilo remains comparable.

One's assessment of the impact of sustainable tourism in Northern Iloilo can bring about viable prospects for the development of sustainable tourism in that area. Perhaps, high impact denotes high viability, as in the case of the residents' assessment of sustainable tourism in Northern Iloilo. Further, improvement in the quality of life, such as employment opportunities, access to resources, amenities and life-support systems, can promote the long term viability of tourism in Northern Iloilo.

The Department of Tourism can continue to integrate sustainable tourism planning into national and regional development plans using the results as a reference. Plans can contain public policy and accountability structures, as well as stakeholder engagement.

Owners of resorts and tourism-related companies should strive to advocate the concept of sustainability and the need for it. Via promotions and promotions of the various tourism destinations in Northern Iloilo, existing promotion and delivery platforms should prioritize sustainability. They can also use cutting-edge and appropriate technologies to enhance resource performance. Future researches on promotion strategies, marketing, and advertising are recommended.

\section{ACKNOWLEDGEMENT}

We would like to thank the Northern Iloilo communities for participating in this study.

\section{REFERENCES}

Bac, D. (2012). The Emergence of Sustainable Tourism-A Literature Review. QUAESTUS Multidisciplinary Research Journal.

Brida, J.G., Osti, L. \& Disegna, M. (2011). Residents' perceptions of tourism impacts and attitudes towards tourism policies in a small mountain community. Retrieved from: https://www.researchgate.net/publication/228124245].

Cernat, L. \& Gourdon, J. (2012). Paths to success: Benchmarking cross-country sustainable tourism. Tourism Management 33,1044-1056. Retrieved from http://dx.doi.org/10.1016/j.tourman.2011.12.007

Chen, C.F. \& Chen, P.C. (2010). Residents' Attitudes towards heritage tourism development. Tourism Geographies, 12 (4), pp. 525-545. Retrieved from http://dx.doi.org/10.1080/14616688.2010.516398 
Chili, N.S. (2015). Perceptions and attitudes of the community towards tourism impact and sustainable development: The case of eMpophomeni in Pietermaritzburg (South Africa). Problems and Perspectives in Management, 13 (3).

Crewell, J. W. (2014). A Concise Introduction to Mixed Methods Research. Sage Publishing

Dwyer, L., Edwards, D., Mistilis, N., Roman, C., \& Scott, N. (2009). Destination and enterprise management for a tourism future. Tourism Management, $30,63-74$.

Egresi, I. (2016). Globalization, Mass Tourism, and Sustainable Development. Alternative Tourism in Turkey,

Gursoy, D., Chi, C. G. \& Dyer, P. (2010). Locals' attitudes toward mass and alternative tourism: The case of Sunshine Coast, Australia. Journal of Travel Research, 49 (3), pp.381-394

Huang, W. (2011). Good Practice in Sustainable Tourism; Developing a Measurement System by Providing A Model Assessment Procedure. Retrieved from https://lup.lub.lu.se/luur/download?func=downloadFile\&recordOId=2173952\&fileOId=2174918

Jackson, L.A. (2008). Residents perceptions of the impacts of special event tourism, Journal of Place Management and Development, 1 (3), pp. 241-255. Available at: http://dx.doi.org/ $10.1108 / 17538330810911244$

Kuvan, Y. \& Akan, P. (2005). Residents' attitudes towards general and forest-related impacts of tourism: The case of Belek, Antalya. Tourism Management, 26 (5), 691-706. Retrieved from http://dx.doi.org/10.1016/ j.tourman.2004.02.019

Libosada, C., and Bosangit, C., (2007). Introduction to Tourism: A Comprehensive Guide to the Travel and Tourism Industry.

Liu, Z.(2003). Sustainable Tourism Development: A Critique. Journal of Sustainable Tourism, 11(6):459-475

Liu, C. H., Tzeng, G. H., Lee, M. H., \& Lee, P. Y. (2013). Improving metro-airport connection service for tourism development: Using hybrid MCDM models. Tourism Management Perspectives, 6, 95-107.

Mbaiwa, Joseph \& Stronza, Amanda. (2010). The effects of tourism development on rural livelihoods in the Okavango Delta, Botswana. Journal of Sustainable Tourism. 18. 635-656. 10.1080/09669581003653500.

Mohammadi, M., Khalifah, Z., and Hosseini H. (2010). Local perceptions toward social, economic and environmental Impacts of Toursim in Kermanshah (Iran). Asian Social Science, 6(11), 220-225.

Murthy, E.K. (2008). Management of tourism and hospitality industry. Jaipur, IND: Global Media.

Pearce DW. The Great Environmental Values Debate. Environment and Planning A: Economy and Space. 1994;26 (9):1329-1338. doi:10.1068/a261329

Stoyanov, Encho (2012). Sustainable Tourism in Reykjavik - skemman.is. (n.d.). Retrieved from http://skemman.is/stream/get/1946/10766/26684/1/Encho_BS_ritger\%C3\%B0.pdf 